\title{
Plague in Athens (Mor v Athénách)
}

Author: Jiři Kolár̆

First Published: 1965

Theatre Premiere: 1972 (the non-verbal first part of the play, Light of the World, Studio DEX 72, Brno).

Translation: French (La Peste d'Athènes, 1986).

Theatre Adaptations: Theater Brett, Vienna (in part, 1978, under the title Die Grube [The Pit]); Theater Brett, Vienna (1991, under the title Alibis); JAMU, Studio Marta, Brno (1998).

Radio Adaptation: Czech Radio, Brno (1993, under the title Mor [The Plague]).

About the Author: Jiři Kolář (1914-2002) was a graphic artist, poet, essayist and translator. He came from Kladno, and he called himself "a simple worker”. He started his creative career in the early 1930 s with surrealist poems, later belonged to the left-oriented artistic and literary Group 42. Due to the Communist coup in 1948, he was banned from 1949 to 1957. In 1950, he wrote one of his substantive books of poetry $\rightarrow$ The Liver of Prometheus. He spent eight months in prison in 1953 for this "subversive manuscript". For which, among others, he used the text by the Czech writer Ladislav Klima and the short story By the Railway Track ( $\rightarrow$ Medallions) by Zofia Nałkowska. At the end of 1950s, he gradually concentrated on artistic work and visual experiments. His visual poetry and collages won him world fame with dozens of exhibitions. His entire work was exhibited in the Guggenheim Museum in New York in 1975 and in other major Western museums of modern art. In the 1970s and 1980s, again, he could not publish except in samizdat or exile. In 1977, Kolář signed the human rights manifesto Charter 77 and while on a scholarship in West Berlin, the Czechoslovak government decided to force him to emigrate with no permission to return. He lived in Paris from 1980 to 1989, and afterwards he regularly travelled between Paris and Prague. From the late 1990s, due to his declining health, he stayed in Prague and spent his last years in a Prague hospital.

Further Important Publications: Očitý svědek (written in 1949, samizdat 1975, Munich 1983, Eyewitness; diaries and poems); Prometheova játra (written in 1950, samizdat 1979, Toronto 1985, $\rightarrow$ The Liver of Prometheus, French 1985, Italian 2009, German 2019; diaries, dreams and poems); Mistr Sun o básnickém umění (1957; Master Sun on the Art of Poetry, poems); Básně ticha (1965, Poems of Silence, visual poems); Chléb náš vezdejši (1965, Our Daily Bread, play).

2 Open Access. () 2021 Agata Firlej, published by De Gruyter. (c) BY-NC-ND This work is licensed under a Creative Commons Attribution-NonCommercial-NoDerivatives 4.0 License. https://doi.org/10.1515/9783110671056-079 


\section{Content and Interpretation}

Jiř́ Kolář wrote only two theatre plays in his life: Our Daily Bread in 1959 and Plague in Athens in 1961. Their form is analogous to the author's artistic collages and prollages; they are rather "constructed" than "written" by the author. As Vladimír Karfík remarked: "The breakage of the traditional dramaturgic form corresponds with a destruction of the world" (Karfík, 1994, p. 70). Each play is doubled - it has a pre-play, seemingly not tied with the main play. The concept of the author, as he said himself, was as follows: "Each play should have two versions: the first straight, as it is written, and the second one oneiric, crazy, on the stage or on the screen, it doesn't matter" (Bauer, 2001, p. 6). Some of the props - for example a bone in the analysed play - are common for the pre-play and the main play.

The work begins with the pantomime named Light of the World (there are two "actors", the Woman and the Arm of a Man). In the play, grotesque and tragic situations come into sight demonstrating the evil and villainy in the history of mankind in its variable forms. Plague in Athens only has one scene, changing from time to time to a prison. The play uses excerpts from The Conquest of Mexico by William H. Prescott, Holocaust memories Otto Kraus's and Erich Kulka's in the book The Death Factory: Document on Auschwitz, reports from South America colonisation, pieces of the sixteenth century treatise of a Spanish friar Bartolomeo de las Casas La Brevisima relación de la destrucción de las Indias, old Egypt texts, the documentary book by Václav Kočka Lidice, the History and the Last Days of the Cottage, history of Russian sects, pieces of biography of Ladislav Klima, the Czech nonconformal writer and philosopher, and the ending of the ancient De rerum natura by Lucretius.

The aforementioned list proves that the main topic of the drama is human malice. The collage form is visible in quotations from other sources inserted in the characters' conversation or in the textual stylisation associated with various discoursive forms easy to be distinguished. This intertextuality serves the project of combining of seemingly distant threads into a composition, which - like in a plastic collage - joins decontextualised pieces in a new entity.

A few times Kolár uses authentic testimonies concerning the Holocaust in his plays. He also introduces stories indirectly pertaining to terrifying pictures of genocide and through this manner shows, thanks to the deliberate omission of hard facts about place and time of the events he talks about, a universal character of the horrible repertoire: loud dance music, shooting people above the pit, burying victims in mass graves. The play is purposefully void of concrete details (where, when, who). Through such solution it activates the memory or cultural connotations of the audience and by eliminating a factual layer that could become a psychological safety valve and distraction. The play forces the audience to focus on the event itself. A collage, in different shapes and variants, as an artistic method, both: discursive and ethical, ties Kolář’s output with the literary and theatre activity of the Polish author Tadeusz Różewicz $\rightarrow$ An Excursion to the Museum. Both authors search for their way of creating literature in non-literary times: non-literary in a sense of the previous understanding of 
literature (seen, according to Bertolt Brecht, as a field that was not ready for concentration camps and crematorium chimneys).

\section{Main Topics and Problems}

In the mid 1950s, Jiři Kolář, who had no Jewish origins, visited Auschwitz Museum. He later wrote about this experience: "For me, it was one of the biggest shocks I experienced: a great glass room full of hair, shoes, suitcases, clothes, prostheses, dishes, glasses, toys etc. Everything marked with a terrible fate, marked with something the art did not comprehend and will not comprehend. Here my skepticism reached its peak in regards to everything that used and uses artificial shock, to everything that ever wanted to provoke, to irritate, to shock, in regards to whatever exhibitionism" (Kolár̆, 1965, p. 6).

This reflection in connection with the author's doubt in a word, rejection of the discursive role of literature as a reservoir of symbols feeding demagogical speeches of ideologists, led him to the idea of the creating or the reprocessing of works from pieces and leaving in them, as he called it, a rift of understatement (or a field of action for the recipient). It can be said that the creative path of Kolár is in a way pars pro toto of an artistic and literary search of many authors reacting to the experience of the Shoah and to many texts describing this hecatomb. Doubt in the previous aesthetics and in the polyphonic load of words is one of the most common experiences in the second half of the 20th century - until now.

Kolář's dramas and a volume Poems of Silence were created in the same time, when the artist started to treat a word not only as a semantic unit but first of all as a graphic and iconoclastic one.

Kolář was the artist who, along with Josef Hiršal, Josef Škvorecký ( $\rightarrow$ The Menor$a h)$ and other young Czech authors, was one of Jiři Weil's ( $\rightarrow$ Life with a Star; $\rightarrow$ Elegy for 77,729 Victims) closest friends, and inspired by his output he doubted in the possibility of a verbal presentation of the war (Shoah). Memory, as Kolář remarks in his diary, is a phenomenon that should be understood as a way of communication. It aspires to be impossibly full and unique. A valued reflection comes later; at the beginning there is only chaos and the tangle of items that are arranged in seemingly coherent sequences, but they contain the seeds of non-obvious inconsistencies. Jiří Kolár sought adequate language, not necessarily woven with words, for artistic expression after the Holocaust.

\section{Cited Works}

Bauer M. (2001). Jiři Kolář: Očitý svědek v zemi mrtvých / Očitý svědek ze země mrtvých. Tvar, 12(14), pp. 6-7. Kolář J. (1965). Snad nic, snad něco. Literární noviny, 14(36), pp. 6-7. 


\section{Further References}

Buršová, A. (2016). Portrét divadla Theater Brett do pádu „železné opony“. Doctoral Thesis. Brno: Janáčkova akademie múzických umění, pp. 80-109. Available at: https:// is.jamu.cz/th/d4mg8/DISERTACE-finalni_verze_25.5.16_29.5._.pdf [Accessed: 02.11. 2019]. Carpenter, J. (1989). Jiři Kolář: Visual Poetry and Verbal Art. Cross Currents, 8, pp. 209-228. Černý, V. (1992). Nástin básnické osobnosti Jiř́ho Koláře. Pokus o genetiku básnika abstraktního. In: V. Černý, Tvorba a osobnost. I. Praha: Odeon, pp. 888889. Engelking L. (1999). Tekst cudzy, tekst własny. Czas Kultury, 15(2), pp. 35-38. Engelking L. (2005). Codzienność i mit. Poetyka, programy i historia Grupy 42 w kontekstach dwudziestowiecznej awangardy i postawangardy. Łódż: Wydawnictwo Uniwersytetu Łódzkiego. Engelking L. (2011). Laleczki na sprzedaż. Zabawa w Holocaust i handel Holocaustem. Muzykalia, 11 (Judaica 3), pp. 1-11. Available at: http://demusica.edu.pl/ wp-content/uploads/2019/07/engelking_muzykalia_11_judaica3.pdf [Accessed:11.04. 2019]. Firlej, A. (2017). From Report to Mythus. Jiři Kolář’s Plays as Creative Transformation of the Shoah Testimonies. Poznańskie Studia Slawistyczne, 6(12), pp. 79-91. Firlej, A. (2016). Nieobecność. Ujęcia Szoa w czeskiej dramaturgii. Poznań: Wydawnictwo Naukowe UAM. Karfík, V. (1994). Jiř Kolâř. Praha: Český spisovatel, pp. 87-102. Kolář J. (2000). Chléb náš vezdejší. Morv Athénách. Ed. V. Karfík. Praha, Litomyšl: Paseka. Ripellino, A. M. (1976). Su Kolář. In: J. Kolář, Collages. Torino: Einaudi, pp. 3-41. 